\title{
Pengaruh Tingkat Ketuaan Daun Terhadap Karakteristik Teh Herbal Matcha Tenggulun (Protium javanicum Burm.F.)
}

\section{The Effect Of Leaves Maturity On Characteristics Of Matcha Tenggulun Herbal Tea (Protium javanicum Burm.F.)}

\author{
Hasbi Rohiqi ${ }^{1}$, N.L. A. Yusasrini ${ }^{* *}$, G.A.K. Diah Puspawati ${ }^{1}$ \\ Program Studi Teknologi Pangan, Fakultas Teknologi Pertanian, Universitas Udayana \\ Kampus Bukit Jimbaran, Badung-Bali \\ *Penulis korespondensi: Ni Luh Ari Yusasrini, Email: ariyusasrini@unud.ac.id
}

\begin{abstract}
The purpose of this study were to determine the effect of leaf maturity on the characteristics of matcha herbal tea tenggulun leaf and to determine the right level of leaf maturity which can produce matcha herbal tea tenggulun leaf with the best characteristics. This study used a completely randomized design (CRD) with, namely very young, young, a little old and old leaves. The parameters observed in this study included moisture content, ash content, crude fiber content, tannin content, total phenol, total flavonoids, antioxidant activity, color and sensory evaluation which included color, aroma, taste and overall acceptance of matcha herbal tea tenggulun leaf. The results showed that the difference in the level of leaf maturity had a very significant effect on moisture content, ash content, crude fiber content, total phenol, total flavonoids, tannin content, antioxidant activity, color and sensory characteristics including color and overall acceptance. However, the level of leaf maturity had no effect on the aroma and taste of matcha herbal tea tenggulun leaves. Matcha herbal tea tenggulun leaves processed from young leaves has the best characteristics with the criteria of water content of $7.93 \%$, ash content of $7.07 \%$, crude fiber content of $13.95 \%$, total phenol $13.36 \%$, total flavonoids $2.39 \%$, tannin content $14.17 \%$ antioxidant activity $79.08 \%$, color with a value of $\mathrm{L}=21.35, \mathrm{a}=-10.46, \mathrm{~b}=14.58$ and the sensory characteristics of color, aroma, taste and overall acceptance were rather liked.
\end{abstract}

Keywords : characteristics, herbal tea, matcha, tenggulun leaf

\section{PENDAHULUAN}

Daun tenggulun merupakan bagian dari tanaman tenggulun yang bisa dimanfaatkan untuk olahan pangan. Di Bali, daun tenggulun biasa dikonsumsi sebagai sayuran atau pelengkap bumbu masakan karena memiliki cita rasa yang khas. Menurut penelitian Enik, (1997), daun tenggulun memiliki kandungan komponen bioaktif yang telah dibuktikan memiliki peran terapeutik dalam pengobatan dan pencegahan suatu penyakit, seperti, antibakteri, antidiabetes, dan antiinflamasi. Eniek, (1997) juga melaporkan bahwa daun tenggulun mengandung senyawa golongan terpenoid, steroid, flavonoid, tannin, dan minyak atsiri. Komponen minyak atsiri yang terkandung dalam daun tenggulun yaitu dari golongan monoterpen seperti $\beta$-ocimen, $\alpha$-pinen dan seskuiterpen seperti $\beta$-kariofilen, germacren, $\alpha$ humulen, $\beta$-elemen, kariofilen oksida, $\alpha$-amorpen, dan spatulenol (Sukmajaya et al., 2012). Berdasarkan komposisi kimia yang terdapat pada daun tenggulun, maka daun tenggulun memiliki potensi untuk dikembangkan sebagai pangan fungsional, diantaranya adalah teh herbal matcha daun tenggulun. 
Teh herbal matcha merupakan salah satu jenis teh herbal berbentuk bubuk yang dibuat dengan satu jenis teh herbal yang diproduksi dengan metode steaming dan mengacu pada proses pembuatan teh hijau matcha. Menurut Preddy (2013) keuntungan mengkonsumsi teh matcha adalah dapat memperoleh senyawa-senyawa dalam teh yang tidak larut dalam air seperti berbagai vitamin larut lemak, serat makanan yang tidak larut air, klorofil, protein, dan lain-lain.Teh biasanya diminum hanya dalam bentuk ekstrak sehingga seluruh senyawa yang tidak larut air terbuang.

Salah satu faktor yang berpengaruh terhadap kualitas teh herbal matcha daun tenggulun adalah tingkat ketuaan daun yang digunakan. Ketuaan daun akan berpengaruh pada kandungan gizi, komponen bioaktif, serta karakteristik sensorinya. Izzreen dan Fadzelly (2013) melaporkan bahwa daun teh (Camellia sinensis) memiliki kadar polifenol yang lebih tinggi pada daun muda dibandingkan dengan daun tua, sedangkan menurut Felicia et al (2016), teh herbal bubuk daun alpukat yang diproses dengan metode steaming memiliki aktivitas antioksidan tertinggi dan karakteristik sensori terbaik pada daun alpukat tua. Demikian juga halnya dengan teh herbal daun tin, semakin tua daun maka kadar air, kadar tanin, dan aktivitas antioksidan teh daun tin semakin menurun. dan berpengaruh nyata terhadap tingkat kesukaan rasa dan penerimaan keseluruhan (Amanto et al., 2020).

Menurut Muthoharoh, (2011) dalam Sari (2015), tingkat ketuaan daun dapat dikelompokkan berdasarkan posisi daun pada batang yaitu daun ketiga dari pucuk (umur fisiologis daun muda), daun keenam dari pucuk (umur fisiologis daun sedang) dan daun kedelapan dari pucuk (umur fisiologis daun tua). Daun tenggulun memiliki tingkatan ketuaan daun tertentu. Bagian pucuk sampai 2 daun dibawahnya adalah daun sangat muda (berwarna merah muda), daun pada posisi 3 sampai 5 dari pucuk adalah daun muda (berwarna hijau muda), serta daun pada ruas dibawahnya adalah daun agak tua (berwarna hijau) dan sangat tua (berwarna hijau tua).

Perbedaan kandungan komponen kimia maupun karakteristik sensori pada teh herbal matcha daun tenggulun berdasarkan tingkat ketuaan daunnya sampai saat ini belum diketahui. Oleh karena itu tujuan penelitian ini adalah untuk mengetahui pengaruh tingkat ketuaan daun terhadap karakteristik teh herbal matcha daun tenggulun dan untuk mengetahui tingkat ketuaan daun yang tepat yang dapat menghasilkan teh herbal matcha daun tenggulun dengan karakteristik terbaik.

\section{METODE PENELITIAN}

\section{Tempat dan Waktu Penelitian}

Penelitian ini dilaksanakan di Laboratorium Analisis Pangan dan Laboratorium Biokimia dan Nutrisi, Fakultas Teknologi Pertanian Universitas Udayana. Penelitian ini dilakukan pada bulan Agustus-Oktober 2020.

\section{Bahan dan Alat}

Bahan-bahan yang digunakan dalam melaksanakan penelitian ini terdiri dari bahan baku dan bahan kimia. Bahan baku utama terdiri dari daun tenggulun dengan tingkat ketuaan daun yang berbeda yaitu : daun sangat muda (pucuk dengan 2 daun di bawahnya), daun muda (daun ke-3 dan ke4 dari pucuk), daun agak tua (daun ke-5 dan ke-6 
dari pucuk) dan daun tua (daun ke-7 dan ke-8 dari pucuk). Bahan baku diambil di seputaran wilayah Bukit Jimbaran, Badung. Bahan kimia yang digunakan terdiri dari DPPH, reagen folinciocalteau, etanol, akuades, asam tanat, reagen follin denis, asam galat, $\mathrm{Na}_{2} \mathrm{CO}_{3}, \mathrm{AlCl}_{3}, \mathrm{NaNO}_{2}$, dan kuersetin.

Alat-alat yang digunakan dalam penelitian ini adalah oven (MKS-FDH10), blender (Philips, Belanda), ayakan 100 mesh, kuas, alumunium foil, spektrofotometer (Genesys 10S UV-Vis), timbangan analitik (Shimadzu), timbangan analitik (Sartorius), vortex, pipet tetes, pipet mikro, tabung reaksi, tabung centifuse, rak tabung reaksi, corong kaca (Pyrex, Jepang), labu ukur, gelas beaker (Pyrex, Jepang), tabung sentrifugasi, centrifuse (Damon), kompor listrik, pipet ukur, loyang aluminum, rubber bulb, botol amber, cawan alumunium, pinset, spatula, kuvet, dan desikator.

\section{Rancangan Percobaan}

Rancangan yang digunakan pada penelitian ini adalah Rancangan Acak Lengkap (RAL) dengan perlakuan tingkat ketuaan daun yang terdiri dari 4 taraf meliputi : P1 = daun sangat muda, P2 = daun muda, P3 = daun agak tua dan P4 = daun tua. Perlakuan diulang sebanyak 4 kali sehingga diperoleh 16 unit percobaan. Data yang diperoleh dianalisa menggunakan sidik ragam dan jika terdapat pengaruh antar perlakuan terhadap variabel yang diamati, maka dilanjutkan dengan uji Duncan'sMultiple Range Test (DMRT) (Gomes dan Gomes, 1995).

\section{Pelaksanaan Penelitian}

Pelaksanaan penelitian meliputi beberapa tahap sebagai berikut:

\section{Pembuatan bubuk teh herbal matcha daun tenggulun}

Pengolahan teh herbal matcha daun tenggulun dilakukan dengan metode pengukusan (steaming) sesuai dengan Topus et al., (2014) yang dimodifikasi. Sebanyak 100 gram daun tenggulun dipisahkan dari batangnya lalu dikukus dengan suhu $100^{\circ} \mathrm{C}$ selama 90 detik. Daun didinginkan selama 5 menit, lalu dikeringkan dalam oven pada suhu $60^{\circ} \mathrm{C}$ dan waktu 5 jam. Daun digiling hingga menjadi bubuk. Bubuk diayak dengan ayakan 100 mesh.

\section{Pembuatan seduhan teh herbal matcha daun tenggulun}

Pembuatan air seduhan teh herbal matcha daun tenggulun dilakukan dengan cara melarutkan sebanyak 1 gram bubuk matcha daun tenggulun ke dalam $80 \mathrm{ml}$ air hangat bersuhu $80^{\circ} \mathrm{C}$. Pengadukan dilakukan dengan menggunakan alat pengaduk teh (chasen) atau dengan milk fronther hingga homogen dan mengeluarkan busa (Gromer, 2009).

\section{Parameter Pengamatan}

Parameter yang diamati dalam penelitian ini adalah kadar air dengan metode oven menurut AOAC (2005), aktivitas antioksidan dengan menggunakan metode DPPH (2,2-diphenyl-lpicrylhidrazyl) (Khan et al., 2012), total fenol menurut Sakanaka et al., (2003), analisis kadar total flavonoid berdasarkan Xu dan Chang (2007), kadar tanin menurut Suhardi (1997) penentuan warna menggunakan alat colorimeter dengan sekala hunter L, $a$ dan $b$ (Topuz et.al 2014) serta uji sensori meliputi warna, aroma, rasa, serta penerimaan keseluruhan. (Soekarto, 1985). 


\section{HASIL DAN PEMBAHASAN}

Nilai rata-rata kadar air, kadar abu dan serat kasar teh herbal matcha daun tenggulun dapat dilihat pada Tabel 1 dan Nilai rata-rata total fenol, total flavonoid, kadar tanin dan aktivitas antioksidan teh herbal matca daun tenggulun tertera pada Tabel 2.

\section{Kadar air}

Hasil sidik ragam menunjukan bahwa tingkat ketuaan daun berpengaruh sangat nyata $(\mathrm{P}<0,01)$ terhadap kadar air teh herbal matcha daun tenggulun. Kadar air terendah diperoleh dari perlakuan P4 (daun tua) sebesar 7,35\%, sedangkan kadar air tertinggi diperoleh dari perlakuan P1 (daun sangat muda) yaitu sebesar 9,15\%. Mengacu pada SNI 3945 : 2016 tentang teh hijau, kadar air yang dipersyaratkan adalah maksimal $8 \%$. Dengan demikian, dari keempat perlakuan maka perlakuan P2 (daun muda), P3 (daun agak tua) dan P4 (daun tua) memenuhi persyaratan SNI tersebut.

Berdasarkan data pada Tabel 1 dapat dilihat bahwa semakin tua daun tenggulun yang digunakan, akan menghasilkan teh herbal matcha dengan kadar air yang semakin menurun. Lakitan 1993 dalam Amanto et al., (2020) melaporkan bahwa pada daun yang tua terdapat sel-sel yang sudah tidak aktif didalamnya. Sel-sel yang sudah tidak aktif ini akan menganggu jalannya transportasi air dari akar ke daun, sehingga dalam daun yang tua mengandung lebih sedikit air. Tingginya kadar air pada daun muda karena pada bagian daun tersebut memiliki lebih banyak sel yang aktif bila dibandingkan dengan daun tua. Dengan demikian kadar air teh herbal matcha daun tenggulun yang berasal dari daun sangat muda (P1) memiliki kadar air yang paling tinggi sedangkan teh herbal matcha yang berasal dari daun tua (P4) memilki kadar air yang paling rendah.

\section{Kadar abu}

Hasil sidik ragam menunjukkan bahwa tingkat ketuaan daun berpengaruh sangat nyata $(\mathrm{P}<0,01)$ terhadap kadar abu teh herbal matcha daun tenggulun. Kadar abu terendah diperoleh dari teh herbal matcha daun tenggulun dari daun sangat muda (P1) sebesar 6,45\% sedangkan kadar abu tertinggi diperoleh dari produk teh herbal matcha daun tenggulun dari daun tua (P4) sebesar 13,44\%. Berdasarkan SNI 3945 : 2016 tentang teh hijau, kadar abu ( $\%$ bb) yang dipersyaratkan adalah antara 4\%-8\%. Dengan demikian, dari keempat perlakuan tersebut, yang memenuhi kriteria persyaratan SNI 4945:2016 adalah produk P1(daun sangat muda), P2 (daun muda) dan P3 (daun agak tua). Berdasarkan data pada Tabel 1, terlihat bahwa kadar abu produk teh herbal matcha daun tenggulun semakin meningkat seiring dengan bertambahnya tingkat ketuaan daun dan saling berbeda nyata satu dengan yang lainnya. Abu merupakan zat anorganik sisa hasil pembakaran suatu bahan organik. Kadar abu erat kaitannya dengan mineral suatu bahan. Mineral yang terdapat dalam suatu bahan dapat berupa garam organik dan garam anorganik (Sudardji et al., 1996). Peningkatan kadar abu pada teh herbal matcha daun tenggulun yang sejalan dengan peningkatan ketuaan daun kemungkinan disebabkan oleh perbedaan letak daun dari posisi akarnya. Tokalioğlu (2012) melaporkan bahwa daun tua yang terletak dekat dengan posisi akar pada umumnya mengandung unsur-unsur yang lebih tinggi dibandingkan jaringan vegetatif lainnya. 
Tanaman lebih mudah mengasimilasi unsur-unsur melalui akar. Peneliti lain juga melaporkan bahwa pertumbuhan jaringan tanaman sangat dipengaruhi oleh penyerapan mineral. Dengan demikian daun yang lebih tua mengandung mineral yang lebih tinggi. Hal ini juga tercermin pada produk teh herbal matcha daun tenggulun yang mana semakin tua daun yang digunakan, maka kadar abu teh herbal matcha daun tenggulun semakin meningkat. Hasil penelitian ini sejalan dengan yang dilaporkan oleh Fatanah et al., (2016) bahwa kandungan mineral pada teh herbal daun Cosmos caudatus lebih tinggi pada daun yang tua dibandingkan dengan daun yang muda.

Tabel 1. Nilai rata-rata kadar air (\%), kadar abu (\%) dan kadar serat kasar (\%) teh herbal matcha daun tenggulun pada berbagai tingkat ketuaan daun

\begin{tabular}{cccc}
\hline \multirow{2}{*}{ Perlakuan } & \multicolumn{3}{c}{ Parameter } \\
\cline { 2 - 4 } & Kadar air $(\% \mathrm{bb})$ & Kadar abu $(\%)$ & Kadar serat kasar $(\%)$ \\
\hline P1 & $9,15 \pm 0,08 \mathrm{a}$ & $6,45 \pm 0,18 \mathrm{c}$ & $6,24 \pm 0.09 \mathrm{~d}$ \\
P2 & $7,93 \pm 0,04 \mathrm{~b}$ & $7,07 \pm 0,07 \mathrm{~b}$ & $13,95 \pm 0,05 \mathrm{c}$ \\
P3 & $7,83 \pm 0,07 \mathrm{c}$ & $8,18 \pm 0,12 \mathrm{c}$ & $16,42 \pm 0,13 \mathrm{~b}$ \\
P4 & $7,35 \pm 0,03 \mathrm{~d}$ & $13,44 \pm 0,05 \mathrm{~d}$ & $18,43 \pm 0,12 \mathrm{a}$ \\
\hline
\end{tabular}

Keterangan: Nilai rata-rata \pm standar deviasi $(\mathrm{n}=4)$. Nilai rata-rata yang diikuti oleh huruf yang berbeda pada kolom yang sama menunjukan perlakuan yang berbeda nyata $(\mathrm{P}<0,05)$.

Tabel 2. Nilai rata-rata total fenol, total flavonoid, kadar tanin dan aktivitas antioksidan (\%) teh herbal matcha daun tenggulun pada berbagai tingkat ketuaan daun

\begin{tabular}{ccccc}
\hline \multirow{2}{*}{ Perlakuan } & \multicolumn{4}{c}{ Parameter } \\
\cline { 2 - 5 } & $\begin{array}{c}\text { Total fenol } \\
(\%)\end{array}$ & $\begin{array}{c}\text { Total flavonoid } \\
(\%)\end{array}$ & $\begin{array}{c}\text { Kadar tanin } \\
(\%)\end{array}$ & $\begin{array}{c}\text { Aktivitas antioksidan } \\
(\%)\end{array}$ \\
\hline P1 & $9,27 \pm 0,01 \mathrm{~d}$ & $1,94 \pm 0,005 \mathrm{~b}$ & $9,89 \pm 0,01 \mathrm{~d}$ & $69,28 \pm 0,13 \mathrm{c}$ \\
P2 & $13,36 \pm 0,03 \mathrm{a}$ & $2,39 \pm 0,33 \mathrm{~b}$ & $14,17 \pm 0,03 \mathrm{a}$ & $79,08 \pm 0,07 \mathrm{a}$ \\
P3 & $10,70 \pm 0,03 \mathrm{~b}$ & $2,26 \pm 0,002 \mathrm{a}$ & $11,38 \pm 0,03 \mathrm{~b}$ & $71,13 \pm 0,06 \mathrm{~b}$ \\
P4 & $10,29 \pm 0,06 \mathrm{c}$ & $2,13 \pm 0,004 \mathrm{a}$ & $10,96 \pm 0,06 \mathrm{c}$ & $68,07 \pm 0,06 \mathrm{~d}$
\end{tabular}

Keterangan: Nilai rata-rata \pm standar deviasi $(\mathrm{n}=4)$. Nilai rata-rata yang diikuti oleh huruf yang berbeda pada kolom yang sama menunjukan perlakuan yang berbeda nyata $(\mathrm{P}<0,05)$.

\section{Kadar serat kasar}

Hasil sidik ragam menunjukan bahwa tingkat ketuaan daun berpengaruh sangat nyata $(\mathrm{P}<0,01)$ terhadap kadar serat kasar teh herbal matcha daun tenggulun. Kadar serat kasar terendah diperoleh dari perlakuan P1 (daun sangat muda) yaitu sebesar $6,24 \%$, sedangkan kadar serat kasar tertinggi diperoleh dari perlakuan P4 (daun tua) yaitu sebesar 18,43\%. Mengacu pada SNI 3945 : 2016 tentang teh hijau, kadar serat kasar yang dipersyaratkan adalah maksimal 16,5\%. Dengan demikian, dari keempat perlakuan maka hanya perlakuan P1 (daun sangat muda), P2 (daun muda) 
dan P3 (daun agak tua) yang memenuhi persyaratan SNI tersebut.

Serat kasar merupakan senyawa yang tidak dapat dicerna dalam organ pencernaan yang terdiri dari sellulosa, hemiselulosa dan lignin (Sudarmadji et al 1996). Pada Tabel 1 dapat dilihat bahwa semakin tua daun yg digunakan sebagai bahan baku pembuatan teh herbal matcha, maka kadar serat kasarnya semakin meningkat secara signifikan. Tilman et al (1998) melaporkan bahwa semakin tua umur tanaman maka kadar serat kasar akan meningkat. Hal ini disebabkan karena lignin (komponen serat kasar) mengalami penebalan khususnya pada dinding sel primer dan sekunder sehingga dinding sel pada jaringan sklerenkim menjadi sangat tebal, kuat dan keras (Hutagaol, 2012 dalam Ys et al., 2014). Kandungan lignin akan meningkat seiring dengan meningkatnya umur tanaman. Zat ini terutama terdapat pada batang, akar dan daun dimana kandungan lignin pada batang lebih tinggi daripada kandungan lignin pada daun. Peneliti lain juga melaporkan bahwa pada tanaman yang lebih tua, sel tanaman akan memiliki kesempatan yang lebih banyak menyusun serabut dinding selnya sehingga serat kasar yang merupakan struktur utama dinding sel semakin banyak jumlahnya.

\section{Total Fenol}

Analisis ragam menunjukkan bahwa tingkat ketuaan daun berpengaruh sangat nyata terhadap total fenol teh herbal matcha daun tenggulun. Total fenol terendah diperoleh dari perlakuan P1 (daun sangat muda) sebesar $9,27 \%$ dan total fenol tertinggi diperoleh dari perlakuan P2 (daun muda) sebesar $13,36 \%$.
Menurut Aziz dan Jack (2015), daun merupakan bagian dari tumbuhan sumber senyawa fenolik. Selama pertumbuhan, tanaman akan mensintesis metabolit sekunder dan senyawa bioaktif dengan jumlah yang berbeda dipengaruhi oleh morfologi daun dan bertambahnya usia daun. Rendahnya kadar fenol pada teh herbal matcha daun tenggulun yang dibuat dari daun sangat muda (P1) kemungkinanan disebabkan oleh proses biosintesis komponen bioaktif belum maksimal sehingga kadarnya masih rendah. Proses biosintesis yang optimum baru tercapai ketika pucuk daun sudah berkembang menjadi daun muda. Hal ini terlihat pada kadar total fenol teh herbal matcha daun tenggulun dari daun muda (P2) kadarnya paling tinggi yaitu 13,36\%. Seiring dengan bertambahnya tingkat ketuaan daun maka akan terjadi penurunan bahkan penghentian biosintesis metabolit sekunder baru sehingga kadarnya menjadi lebih rendah pada daun yang lebih tua (Fawole and Opara, 2013). Dengan demikian, teh herbal matcha daun tenggulun memiliki kadar total fenol yang semakin menurun secara signifikan pada perlakuan P3 (daun agak tua) dan P4 (daun tua). Hasil penelitian ini serupa dengan yang dilaporkan oleh Rauf et al (2017) bahwa teh herbal dari daun alpukat muda memiliki kadar polifenol yang lebih tinggi dibandingkan dengan teh herbal alpukat dari daun tua.

\section{Total Flavonoid}

Berdasarkan analisis ragam, tingkat ketuaan daun berpengaruh sangat nyata $(\mathrm{P}<0,01)$ terhadap total flavonoid teh herbal matca daun tenggulun. Total flavonoid tersebut berkisar antara 1,94\% $2,39 \%$. Total flavonoid teh herbal matcha daun 
tenggulun terendah diperoleh dari perlakuan P1 (daun sangat muda) sedangkan total flavonoid tertinggi diperoleh dari perlakuan P2 (daun muda).

Flavonoid termasuk senyawa fenolik yang biasa ditemukan pada batang, daun, bunga, dan buah (Waji dan Andis, dalam Tehubijuluw et al., 2018). Perbedaan kandungan flavonoid pada teh herbal matcha daun tenggulun dipengaruhi oleh tingkat ketuaan daun yang digunakan. Berdasarkan Tabel 2 diketahui bahwa teh herbal matcha daun tenggulun dari daun sangat muda (P1) mengandung flavonoid yang paling rendah. Peningkatan kadar flavonoid terdapat pada teh herbal matcha daun tenggulun dari daun muda (P2). Namun, pada teh herbal matcha daun tenggulun dari daun agak tua (P3) dan daun tua (P4), kadar flavonoid mengalami penurunan. Farhoosh et al, (2007) melaporkan bahwa faktor yang mempengaruhi kadar total flavonoid dalam daun adalah morfologi dan bertambahnya usia daun, yang juga akan mempengaruhi metabolit sekunder dan senyawa bioaktif yang dihasilkan. Bhakta dan Ganjewala (2009) menambahkan bahwa variasi kandungan flavonoid disebabkan karena perbedaan usia perkembangan daun yang terjadi pada lokasi daun yang berbeda. Hasil penelitian ini serupa dengan yang dilaporkan Izzreen dan Fadzelly (2013) bahwa pada daun teh (Camellia sinensis), kadar flavonoid daun muda lebih tinggi daripada kadar flavonoid daun tua.

\section{Kadar Tanin}

Berdasarkan data pada Tabel 2 menunjukkan bahwa tingkat ketuaan daun berpengaruh sangat nyata terhadap kadar tanin teh herbal matcha daun tenggulun. Kadar tanin tersebut berkisar antara
$9,89 \%-14,17 \%$ yang mana kadar tanin terendah diperoleh dari teh herbal matcha daun tenggulun dari daun sangat muda (P1) dan kadar tanin tertinggi diperoleh dari perlakuan P2 (daun muda).

Tanin banyak terdapat di dalam tumbuhan berpembuluh, khususnya dalan jaringan kayu, selain itu banyak terdapat pada bagian daunnya. Kadar bahan aktif di dalam tanaman (termasuk tanin) dipengaruhi oleh beberapa faktor antara lain : tempat tumbuh, derajat kematangan/tingkat ketuaan, varietas, bagian tanaman yang digunakan dan cara pemanenan (Hernani et al, 1990). Tinungki et al (2018) melaporkan bahwa terdapat perbedaan jumlah komponen kimia (bioaktif) dan konsentrasi dari komponen kimia yang terkandung dalam berbagai tingkat perkembangan daun. Pada daun benalu langsat, daun muda memiliki total jumlah komponen kimia terbanyak dibandingkan dengan daun tua dan daun pucuk.

Pada daun yang masih sangat muda, kemungkinan biosintesis tanin belum maksimal dan baru mencapai kadar yang optimum pada daun muda. Hal ini terlihat pada produk teh herbal matcha daun tenggulun dari daun sangat muda (P1) mengandung tanin yang lebih rendah secara signifikan dibandingkan dengan teh herbal matcha daun tenggulun dari daun muda (P2). Bertambahnya tingkat ketuaan daun, menyebabkan kadar tanin semakin menurun. Hasil penelitian ini serupa dengan yang dilaporkan oleh Amanto et al., (2020), bahwa kadar tanin teh herbal daun tin yang berasal dari daun muda lebih tinggi dibandingkan dengan daun tua. 


\section{Aktivitas antioksidan}

Analisis sidik ragam menunjukkan bahwa tingkat ketuaan daun berpengaruh sangat nyata terhadap aktivitas antioksidan teh herbal matcha daun tenggulun. Aktivitas antioksidan tersebut berkisar antara 69,28\% - 79,08\%. Aktivitas antioksidan tertinggi diperoleh dari teh herbal matcha daun tenggulun berbahan baku daun sangat muda (P1) sedangkan aktivitas antioksidan terendah diperoleh dari teh herbal matcha daun tenggulun dari daun muda (P2). Tingginya aktivitas antioksidan pada perlakuan P2 (daun muda) sejalan dengan kadar total fenol, tanin dan flavonoid yang juga tinggi pada perlakuan P2 (daun muda). Hal ini menunjukkan bahwa total fenol, tanin dan flavonoid berkorelasi positif terhadap aktivitas antioksidan teh herbal matcha daun tenggulun. Penurunan aktivitas antioksidan pada teh herbal matcha daun tenggulun dari daun agak tua (P3) dan daun tua (P4) kemungkinan disebabkan oleh penurunan produksi metabolit sekunder seperti tanin, fenol dan flavonoid. Hal ini akan menurunkan kemampuan sistem pertahanan tanaman untuk menetralkan kelebihan produksi spesies oksigen reaktif yang distimulasi oleh proses penuaan (Siddiqui et al., 2013).

$$
\text { Menurut Fawole and Opara (2013) }
$$
penurunan aktivitas antioksidan juga bisa disebabkan karena terjadi penghentian biosintesis metabolit sekunder baru selama pematangan. Sebagian besar biosintesis baru ini terjadi pada tahap awal pertumbuhan tanaman sehingga aktivitas antioksidannya menjadi lebih tinggi pada daun muda. Hasil penelitian ini sejalan dengan yang dilaporkan oleh Fatanah et al., (2016) bahwa aktivitas antioksidan pada teh herbal daun Cosmos caudatus lebih tinggi pada daun yang muda dibandingkan dengan daun yang tua. Teh herbal daun tin yang diolah dari daun tua juga dilaporkan memiliki aktivitas antioksidan yang lebih kecil dibandingkan dengan daun muda (Amanto et al., 2020.

\section{Warna}

Hasil sidik ragam menunjukkan bahwa tingkat ketuaan daun berpengaruh sangat nyata $(\mathrm{P}<0,01)$ terhadap warna air seduhan teh herbal matcha daun tenggulun Nilai rata-rata warna air seduhan teh herbal matcha daun tenggulun dapat dilihat pada Tabel 3.

Tabel 3. Nilai rata-rata $L, a^{*}$ dan $b^{*}$ air seduhan teh herbal matcha daun tenggulun.

\begin{tabular}{cccc}
\hline Perlakuan & Nilai $L$ & Nilai a* & Nilai $\mathrm{b}^{*}$ \\
\hline P1 & $20,56 \pm 0,22 \mathrm{~d}$ & $-9,56 \pm 0,29 \mathrm{a}$ & $15,49 \pm 0,17 \mathrm{~d}$ \\
P2 & $21,35 \pm 0,20 \mathrm{c}$ & $-10,46 \pm 0,16 \mathrm{~b}$ & $14,58 \pm 0,33 \mathrm{c}$ \\
P3 & $23,34 \pm 0,36 \mathrm{~b}$ & $-11,73 \pm 0,34 \mathrm{c}$ & $13,52 \pm 0,29 \mathrm{~b}$ \\
P4 & $25,71 \pm 0,25 \mathrm{a}$ & $-12,52 \pm 0,28 \mathrm{~d}$ & $12,47 \pm 0,18 \mathrm{a}$
\end{tabular}

\footnotetext{
Keterangan : Nilai rata - rata yang diikuti oleh huruf yang berbeda pada kolom yang sama menunjukkan perlakuan yang berbeda nyata $(\mathrm{P}<0,05)$

$\mathrm{L}=$ parameter kecerahan (Nilai $\mathrm{L}=0$ (hitam), $\mathrm{L}=100$ (putih))

$\mathrm{a} *=$ kordinat warna merah hingga hijau ( Nilai $\mathrm{a}=+60($ merah), $\mathrm{a}=-60$ (hijau))

$\mathrm{b} *=$ kordinat warna kuning hingga biru (Nilai $\mathrm{b}=+60$ (kuning), $\mathrm{b}=-60$ (biru))
} 
Warna merupakan salah satu karakteristik pada produk pangan yang dapat dijadikan indikator mutu suatu produk. Menurut Desrosier (1969), warna bahan pangan dipengaruhi oleh kondisi permukaan bahan pangan dan kemampuannya untuk memantulkan, menyebarkan, menyerap dan meneruskan sinar yang nampak. Nilai lightness menunjukkan gelap terangnya (kecerahan) suatu warna (Winarno, 2004). Menurut Hutching (1999), notasi L menyatakan parameter kecerahan (lightness) yang mempunyai nilai 0 (hitam) sampai dengan 100 (putih). Notasi a adalah koordinat warna merah sampai hijau yang mempunyai nilai +60 (merah) dan -60 (hijau), sehingga semakin minus nilai a maka warna air seduhan teh semakin hijau. Notasi b menunjukkan warna kuning hingga biru dimana +60 (kuning) dan -60 (biru), sehingga semakin positif nilai $\mathrm{b}$ maka warna air seduhan semakin kuning.

Berdasarkan data pada Tabel 3 dapat dilihat bahwa semakin tua daun tenggulun yang digunakan, maka kecerahan air seduhan teh herbal matcha akan semakin meningkat. Jika dilihat dari nilai a maka semakin tua daun tenggulun yang digunakan maka akan menghasilkan air seduhan yang lebih berwarna kehijauan, sedangkan jika dilihat dari nilai b maka semakin muda daun yang digunakan, akan menghasilkan air seduhan yang berwarna kekuningan.

Warna air seduhan teh herbal matcha daun tenggulun dipengaruhi oleh kandungan klorofil yang ada dalam produk tersebut. Kandungan klorofil pada daun sangat bervariasi tergantung pada tingkat ketuaan daunnya. Pada daun yang masih sangat muda dan berwarna merah kecoklatan mengandung klorofil dalam jumlah sedikit. Warna daun merah kecoklatan pada pucuk menunjukkan karotenoid merupakan pigmen dominan pada tingkat perkembangan tersebut. Perubahan warna daun dari merah kecoklatan menjadi hijau kekuningan menunjukkan adanya perubahan kandungan pigmen pada daun. Seiring dengan tingkat perkembangan daun akan terjadi sintesis klorofil $b$ dari klorofil a dengan jumlah yang besar, yang ditandai dengan berubahnya warna daun hijau muda menjadi hijau tua (Sumenda et al., 2011). Dengan demikian, perubahan warna pada daun ini akan berpengaruh terhadap warna air seduhan teh herbal matcha daun tenggulun.

\section{Karakteristik sensori}

Penilaian sensori teh herbal matcha daun tenggulun dilakukan oleh panelis semi terlatih. Parameter yang diuji meliputi warna, aroma, rasa, dan penerimaan keseluruhan dengan menggunakan uji hedonik (kesukaan). Nilai rata-rata penerimaan panelis terhadap karakteristik sensori teh herbal matcha daun tenggulun dapat dilihat pada Tabel 4.

\section{Warna}

Hasil sidik ragam menunjukkan bahwa perbedaan tingkat ketuaan daun berpengaruh sangat nyata $(\mathrm{P}<0,01)$ terhadap warna seduhan teh herbal matcha daun tenggulun. Tabel 4 menunjukkan bahwa nilai rata-rata tertinggi warna teh herbal matcha daun tenggulun diperoleh pada perlakuan P4 (daun tua) yaitu dengan kiteria suka sedangkan nilai rata-rata terendah diperoleh dari perlakuan P1 (daun sangat muda dengan kriteria agak tidak suka. Tingkat ketuaan daun berpengaruh terhadap kandungan klorofil pada daun daun. Daun tenggulun tua memilki kandungan klorofil lebih 
banyak dibandingkan daun tenggulun muda. Menurut Mayasari (2016) kandungan klorofil pada daun meningkat seiring bertambahnya umur daun.
Apabila diamati secara visual maka semakin tua daun maka daun berwarna hijau tua. Perlakuan P4 (daun tua).

Tabel 4. Nilai rata-rata hasil uji organoleptik teh herbal matcha daun tenggulun

\begin{tabular}{ccccc}
\hline \multirow{2}{*}{ Perlakuan } & Warna & Aroma & Rasa & $\begin{array}{c}\text { Penerimaan } \\
\text { keseluruhan }\end{array}$ \\
\cline { 2 - 5 } & $3,35 \mathrm{c}$ & $4,35 \mathrm{a}$ & $3,35 \mathrm{a}$ & $3,90 \mathrm{~b}$ \\
\hline P1 & $3,70 \mathrm{bc}$ & $4,30 \mathrm{a}$ & $3,55 \mathrm{a}$ & $3,70 \mathrm{~b}$ \\
\hline P2 & $4,00 \mathrm{~b}$ & $4,50 \mathrm{a}$ & $3,75 \mathrm{a}$ & $4,10 \mathrm{~b}$ \\
\hline P3 & $4,75 \mathrm{a}$ & $4,85 \mathrm{a}$ & $3,85 \mathrm{a}$ & $4,70 \mathrm{a}$ \\
\hline P4 &
\end{tabular}

Keterangan : Nilai rata - rata yang diikuti oleh huruf yang berbeda pada kolom yang sama menunjukkan perlakuan yang berbeda nyata $(\mathrm{P}<0,05)$

Skala uji hedonik : 1) sangat tidak suka, 2) tidak suka, 3) agak tidak suka, 4) agak suka, 5) suka, 6) sangat suka.

\section{Aroma}

Hasil sidik ragam menunjukkan bahwa perbedaan tingkat ketuaan daun tidak berpengaruh nyata $(P>0,05)$ terhadap aroma seduhan teh herbal matcha daun tenggulun. Berdasarkan data pada Tabel 4 menunjukkan bahwa rata-rata panelis menyukai aroma air seduhan dengan kriteria agak suka. Daun tenggulun memiliki aroma yang asam yang khas. Aroma yang khas dari daun tenggulun dapat dirasakan oleh indera penciuman panelis. Peran aroma terhadap produk dapat mempengaruhi minat konsumen untuk mencoba suatu produk makanan. Aroma dalam suatu bahan makanan atau minuman dapat ditimbulkan oleh komponenkomponen volatile, akan tetapi komponen volatile tersebut dapat hilang selama proses pengolahan terutama terhadap panas (Fellow,1990).

\section{Rasa}

Analisis ragam menunjukkan bahwa perbedaan tingkat ketuaan daun tidak berpengaruh nyata $(\mathrm{P}>0,05)$ terhadap rasa seduhan teh herbal matcha daun tenggulun. Data pada Tabel 4 menunjukkan bahwa panelis agak tidak menyukai rasa air seduhan teh herbal matcha daun tenggulun. Teh herbal matcha daun tenggulun memiliki rasa agak pahit (sepat). Rasa pahit yang terkandung pada teh herbal matcha daun tenggulun kemungkinan berasal dari senyawa polifenol berupa katekin

\section{Penerimaan Keseluruhan}

Penerimaan keseluruhan dilakukan untuk mengetahui tingkat kesukaan panelis secara keseluruhan terhadap air seduhan teh herbal matcha daun tenggulun. Analisis ragam menunjukkan bahwa perbedaan tingkat ketuaan daun berpengaruh sangat nyata $(\mathrm{P}<0,01)$ terhadap penerimaan keseluruhan air seduhan teh herbal matcha daun tenggulun. Pada Tabel 4 terlihat bahwa nilai rata-rata tertinggi penerimaan keseluruhan teh herbal matcha daun tenggulun diperoleh pada perlakuan P4 (daun tua) dengan kriteria suka dan nilai terendah diperoleh pada perlakuan P2 (daun muda) dengan kriteria agak suka. Hal ini menunjukkan bahwa secara 
keseluruhan panelis menyukai air seduhan teh herbal matcha daun tenggulun. Dalam hal ini, teh herbal matcha daun tenggulun yang diolah dari daun tua lebih disukai panelis dibandingkan dengan produk yang lainnya.

\section{KESIMPULAN DAN SARAN}

\section{Kesimpulan}

Perbedaan tingkat ketuaan daun berpengaruh sangat nyata terhadap kadar air, kadar abu, kadar serat kasar, total fenol, total flavonoid, kadar tanin, aktivitas antioksidan, warna dan karakteristik sensori yang meliputi warna dan penerimaan keseluruhan.

Teh herbal matcha daun tenggulun yang terbaik pada tingkat ketuaan daun muda dengan karakteristik kadar air 7,93\%, kadar abu 7,07\%, kadar serat kasar $13,95 \%$, total fenol $13,36 \%$, total flavonoid 2,39\%, kadar tanin 14,17\% aktivitas antioksidan 79,08\%, warna dengan nilai $\mathrm{L}=21,35$, $\mathrm{a}=-10,46, \mathrm{~b}=14,58$ serta karakteristik sensori warna, aroma, rasa dan penerimaan keseluruhan agak disukai.

\section{Saran}

Untuk memperoleh teh herbal matcha daun tenggulun yang berkarakteristik baik disarankan menggunakan daun muda, namun demikian perlu dilakukan kajian lebih lanjut mengenai upaya perbaikan karakteristik sensori teh herbal matcha daun tenggulun sehingga mampu meningkatkan kesukaan panelis terhadap produk tersebut.

\section{DAFTAR PUSTAKA}

Eniek, K. 1997. Identifikasi, Struktur Anatomi dan Studi Pendahuluan Golongan Senyawa Kimia Daun Pelengkap Bumbu Lawar dan Betutu. F.Mipa. Universitas Udayana. Jimbaran.
Amanto, B. S., T. N. Aprilia., \&A. Nursiwi. 2020. Pengaruh Lama Blanching dan Rumus Petikan Daun Terhadap Karakteristik Fisik, Kimia, Serta Sensoris Teh Daun Tin (Ficus carica). Jurnal Teknologi Hasil Pertanian, Vol. XII, No. 1.

AOAC, 2005. Official Methods of Analiysis. Asosiation Of official Chemist. Inc Virginia.

Badan Standarisasi Nasional Indonesia. 2016. SNI 3945 : 2016, Teh Hijau Bubuk.

Bhakta, D dan D.J. Ganjewala. 2009. Tea, Kombucha, and Health: A Review. Journal of Food

Desrosier, N. W. 1969. The Technologi of Food Preservation. Diterjemahkan oleh Muljohardjo, M. 1988. Teknologi Pengawetan Pangan. Universitas Indonesia Press.Jakarta

Farhoosh, R., G. A. Golmovahhed, and M. H.H. Khodaparast. 2007. Antioxidant Activity of Various Extracts of Old TeaLeaves and Black Tea Wastes (Camellia sinensis L.). Food

Fatanah, D. N., Abdullah, N., Hashim, N., \& Abd Hamid, A. (2016). Antioxidant Activity, Colour And Mineral Content Of Herbal Tea Prepared From Cosmos Caudatus Leaves At Different Maturity Stages. Malaysian Journal Of Analytical Science.

Felicia, N. I.W.R.Widarta.dan N.L.A.Yusasrini 2016. Pengaruh Ketuaan Daun dan Metode Pengolahan Terhadap Aktivitas Antioksidan Serta Karakteristik Sensoris Teh Herbal Bubuk Daun Alpukat (Persea americana Mill). Skripsi Program Study Ilmu dan Teknologi Pangan.Universitas Udayana. Bukit Jimbaran.

Fellow, P.J. 1990. Food Processing Technology. Principle and Practice. Ellis Horwood. New York.

Fawole, O. A. and Opara, U. L. 2013. Changes in physical properties, chemical and elemental composition and antioxidant capacity of pomegranate (cv. Ruby) fruit at five maturity stages. Science Horticulture (Amsterdam)., 150: $37-46$.

Gomes, K.A. dan A.T. Gomes. 1995. terjemahan E. Sjamsudin dan J.S. Baharsyah. Prosedur Statistik Untuk Penelitian Pertanian. UI Press. Jakarta.

Hernani, S. Yuliani, D. Sumangat and E. Mulyono, 1990. The Important Role of Postharverst Technologi in Maintaining The Quality of Product Medicinal Crops. Proceedings The International Congress of Traditional Medicine and Medicinal Plants. Denpasar. Bali. Unpublised.

Hutching, J.B. 1999. Food Colour and Appereance. Aspen Publisher. Inc. Marylan 
Izzreen, N.Q., dan M. Fadzelly. 2013. Phytochemicals and Antioxidant Properties of Different Parts of Camellia sinensis leaves from Sabah TeaPlantation in Sabah, Malaysia. IFJR 20(1):307-312

Mayasari eva. 2016. Pengaruh Tingkat Ketuaan Daun Sokai Segar (Albertisia Papuana Becc.) Terhadap Kadar Asam Amino Glutamat Bebas. Program Studi Ilmu dan Teknologi Pangan. Universitas Tanjungpura. Pontianak.

Muthoharoh, L. 2011. Analisis Berbagai Pigmen Daun Sirih Hijau (Piper betle L.) dan Sirih Merah (Piper crocatum Ruiz \& Pav.) Berdasarkan Umur Fisiologis Daun. Skripsi (Tidak dipublikasikan). Universitas Negeri Malang. Malang.

Preedy, V. R. 2014. Processing and Impact on Antioxidants in Beverages, Academic press, Massachusetts.

Sakanaka, S., Y. Tachibana, dan Y. Okada. 2013. Preparation and antioxidant properties of extracts of japanese persimo leaf tea (kakinochacha). Food chemistry. 89:569-575.

Siddiqui, M. W., Momin, C. M., Acharya, P., Kabir, J., Debnath, M. K., \& Dhua, R. S. 2013. Dynamics of changes in bioactive molecules and antioxidant potential of Capsicum chinense Jacq. cv. Habanero at nine maturity stages. Acta Physiologiae Plantarum.

Soekarto, S.T. 1985. Penilaian Organoleptik Untuk Industri Pangan dan Pertanian. Bharata Karya Aksara. Jakarta.

Sudarmadji, S., B. Haryono, dan Suhardi. 1997. Prosedur Analisis untuk Bahan Makanan dan Pertanian. Liberty, Yogyakarta.

Suhardi. 1997. Analisis Senyawa Polifenol Produk Buah-buahan dan Sayuran.. Laboratorium Kimia-Biokimia Pengolahan Fakultas Teknologi Pertanian Universitas Gadjah Mada, Yogyakarta.
Sukmajaya. I. G., N. M. Puspawati, dan A. A. B. Putra.2012. Analisis Kandungan Minyak Atsiri Daun Tenggulun (Protium javanicum Burm.F.) Dengan Metode Kromatografi GasSpektroskopi Massa. Jurnal Kimia 6(2),:155162.

Sumenda, L., H. L. Rampe, dan F. R. Mantiri.2011. Analisis Kandungan Klorofil Daun Mangga (Mangifera indica L.) pada Tingkat Perkembangan Daun yang Berbeda. . Jurnal Bioslogos,

Tillman, A. D, H. Hartadi, S. Reksohadiprodjo, S. Prawirokusumo, dan S. Lebdosoekojo. 1998. Ilmu Makanan Ternak Dasar. Gadjah Mada Press, Yogyakarta.

Tokalioğlu, Ş. (2012). Determination of trace elements in commonly consumed medicinal herbs by ICP-MS and multivariate analysis. Food Chemistry.

Topuz, A., C. Dincer, M. Torun, I. Tontul, H. S. Nadeem, A. Haznedar, F. Ozdemir. 2014. Physicochemical Properties of Turkish Green Tea Powder: Effects of Shooting

Period, Shading, and Clone. Turkish Journal Of Agriculture and Forestry 38:233-241.

Tehubijuluw, H., T. Watuguly, dan P.M.J. Tuapattinaya. 2018. Analisis Kadar Flavonoid pada Teh Daun Lamun (Enhalus acoroides) Berdasarkan Tingkat Ketuaan Daun. Biopendix, 5, (1) : 01-07

Winarno, F. G. 1995. Kimia Pangan dan Gizi. Gramedia Pustaka Utama, Jakarta.

Xu, B. J., S. K. C. \& Chang. 2007. A comparative on phenolic profiles and antioxidant activities of legumes as affected by extraction solvents. Journal of food Science. 72(2):159-166.

Yudana, I. G. A. 2004. Mengenal Ragam dan Manfaat Teh. http://www.indomedia.com/. Diakses Tanggal 19 November 2019. 